\title{
Effect of the seagrass Zostera capricorni on sediment microbial processes
}

\author{
Jens W. Hansen ${ }^{2, *}$, James W. Udy ${ }^{1}$, Christine J. Perry ${ }^{1}$, William C. Dennison ${ }^{1}$, \\ Bente Aa. Lomstein ${ }^{2}$ \\ ${ }^{1}$ Department of Botany, University of Queensland, Brisbane, Queensland 4072, Australia \\ ${ }^{2}$ Department of Microbial Ecology, Institute of Biological Sciences, University of Aarhus, Bldg. 540, Ny Munkegade, \\ 8000 Aarhus C., Denmark
}

\begin{abstract}
The effect of the seagrass Zostera capricorni on sediment microbial processes was studied in a tank experiment, where vegetated and unvegetated control sediments were incubated in 10 and $50 \%$ of incident light. Leaf and root-rhizome biomass, shoot density, and leaf productivity were significantly higher when plants were incubated in $50 \%$ than in $10 \%$ of incident light. Nitrogen fixation, sulphate reduction, and urea turnover in the $Z$. capricorni vegetated sediment were higher in the $50 \%$ than in the $10 \%$ light treatment and higher in the vegetated than in the unvegetated sediment. The stimulation of microbial processes in the $Z$. capricorni vegetated sediment took place in the rhizosphere, where nitrogen fixation and sulphate reduction in particular were stimulated. The sediment studies were supplemented by measurements of nitrogen fixation, sulphate reduction, and urea turnover by microorganisms associated with the roots and rhizomes of $Z$. capricorni. The rates of nitrogen fixation and sulphate reduction associated with root-rhizomes were up to 40 - and 7 -fold higher, respectively, than the highest respective sediment rates, whereas the root-rhizome associated urea turnover was lower than sediment rates. Nitrogen fixation and sulphate reduction associated with rootrhizomes could account for up to 39 and $4 \%$, respectively, of the depth-integrated sediment rates. Nitrogen fixed by microorganisms associated with root-rhizomes could supply up to $65 \%$ of the nitrogen needed for plant growth. Further, it was estimated that 8 to $18 \%$ of the carbon fixed by $Z$. capricorni was released to the sediment by the roots and rhizomes. Urea turnover was suggested to be an important intermediate in the gross production of ammonium, and a low net production of ammonium indicated rapid internal nitrogen cycling within the sediment.
\end{abstract}

KEY WORDS: Zostera capricorni $\cdot$ Sediment $\cdot$ Roots $\cdot$ Rhizomes $\cdot$ Microbial processes $\cdot$ Light

\section{INTRODUCTION}

Several studies have demonstrated that seagrasses affect nutrient concentrations and microbial processes in the sediment (Short 1983, Caffrey \& Kemp 1990, Short et al. 1993, Pedersen et al. 1997, RisgaardPetersen et al. 1998). This is mainly due to the increased accumulation of nutrients and carbon in seagrass vegetated sediments caused by (1) plant biomass production within the seagrass meadow of which a part is mineralised within the seagrass bed, (2) in-

\footnotetext{
-Present address: National Environmental Research Institute, Vejlsøvej 25, 8600 Silkeborg, Denmark.

E-mail: jwh@dmu.dk
}

creased sedimentation and decreased resuspension in seagrass beds, and (3) leakage of photosynthates from root-rhizomes.

The root-rhizome complex is an important component of the sediment in seagrass beds, as the total surface area and the total length of root-rhizomes often exceeds $1 \mathrm{~m}^{2}$ and $100 \mathrm{~m}$, respectively, per $\mathrm{m}^{2}$ sediment (Smith et al. 1979). Also, the production of roots and rhizomes is often comparable to leaf production (Abal et al. 1994, Duarte et al. 1998). Leakage of photosynthates from root-rhizomes affects sediment microbial processes as demonstrated by the stimulation of nitrogen fixation, sulphate reduction, and bacterial growth in the rhizosphere and the diurnal variation in these processes (Moriarty \& Pollard 1982, Pollard \& Moriarty 
1991, Blackburn et al. 1994, Welsh et al. 1996, Blaabjerg et al. 1998, McGlathery et al. 1998). Further, high rates of nitrogen fixation and sulphate reduction have been measured in incubations of roots and rhizomes of seagrasses (Capone \& Budin 1982, Smith \& Hayasaka 1982a,b, Blaabjerg \& Finster 1998).

Light is the principal factor regulating growth, biomass, and distribution of seagrasses (Wium-Andersen \& Borum 1984, Dennison 1987, Duarte 1991, Nelson \& Waaland 1997). Accordingly, reduced light availability caused by an eutrophication-dependent increase in phytoplankton and epiphytes, and an increase in suspended inorganic particles, has been responsible for most of the decline in the distribution of seagrasses during the last few decades (Duarte 1995, Abal \& Dennison 1996, Borum \& Sand-Jensen 1996, Olesen 1996, Short \& Wyllie-Echeverria 1996, Lee 1997). Due to the effect of seagrasses on sediment pools and processes, light-regulated changes in seagrass populations have an impact on microbial processes in vegetated sediments. However, the interaction between seagrasses and sediment microbial processes has not been thoroughly investigated.

The objective of this study was to evaluate the effect of Zostera capricorni on nitrogen fixation, sulphate reduction, urea turnover, and net ammonium production within the sediment. The experiment was carried out at 2 different light levels to examine the effect of reduced light availability on sediment microbial processes in areas vegetated by seagrasses. Nitrogen fixation, sulphate reduction, and urea turnover were also measured in incubations of root-rhizomes to estimate if the plant's effect on sediment rates were due to processes associated directly with root-rhizomes.

\section{MATERIALS AND METHODS}

Sampling and incubation. Seagrasses cover extensive areas in Moreton Bay, Queensland, Australia, and Zostera capricorni is the most dominant of the 6 species present (Hyland et al. 1989). Plants and sediment were collected in March 1996 from the intertidal part of a monotypic $Z$. capricorni meadow near Victoria Point on the western shore of Moreton Bay. The water temperature was $32^{\circ} \mathrm{C}$ and the salinity $34 \%$. Sediment cores with plants were taken with a corer (inner diameter, i.d., $15 \mathrm{~cm}$ ) which removed a $15 \mathrm{~cm}$ deep plug. The sediment plugs were placed in plastic flower pots lined with a plastic bag, overlaid with ambient water and transported to seawater tanks.

The plants were incubated for $5 \mathrm{wk}$ in $2001(40 \mathrm{~cm}$ deep) outdoor Fiberglas tanks at the CSIRO Cleveland Marine Laboratory. Sand-filtered seawater from the western Moreton Bay was pumped through the tanks at a rate of $\sim 1401 \mathrm{~h}^{-1}$ with a resultant water residence time in the tanks of $\sim 1.4 \mathrm{~h}$. Water temperature was 23 to $29^{\circ} \mathrm{C}$ during the incubation period with a daily variation of $-3^{\circ} \mathrm{C}$, and salinity was $-34 \%$. The water was kept saturated with oxygen by bubbling with atmospheric air. The pots were distributed in 4 tanks with 8 pots in each tank. Leaves and most root-rhizomes were removed from 3 pots in each tank to establish unvegetated control sediment. The tanks were covered with shade screens, which reduced the light irradiance to $\sim 50$ or $\sim 10 \%$ of incident light in each of 2 tanks. The growth of Zostera capricorni was light saturated in the $50 \%$ treatment (Abal et al. 1994), whereas the light irradiance at the $10 \%$ treatment was close to the light compensation point of seagrasses (Duarte 1991, Dennison et al. 1993). Once or twice a week the tanks were scrubbed clean of periphyton, and epiphytes were removed from the seagrass leaves by hand. Each pot was considered as 1 experimental unit.

Plant and sediment characteristics. Leaf growth rate was measured by the leaf marking technique (SandJensen 1975). Leaves in 1 pot from each tank were punched with a needle at the end of the 5 wk incubation period and harvested $10 \mathrm{~d}$ later. The number of shoots in each of these pots was counted at harvest, and the plant material was washed and dried at $60^{\circ} \mathrm{C}$ to constant weight. Leaf production was estimated from the dry weight of the new growth by 10 shoots pot $^{-1}$. The maximum canopy height was noted as the length of the longest leaf. Leaf productivity, maximum canopy height, and plant biomass were measured on plants from the same pots. The turnover time of leaves was estimated as the total leaf biomass divided by the leaf production. The vertical distribution of the rootrhizome biomass was determined in 1 sediment core $(3.2 \mathrm{~cm}$ i.d.) from each tank.

Total organic carbon (TOC) and total organic nitrogen (TON) contents of leaves, root-rhizomes, and sediment (with root-rhizomes removed) were determined on dried, $\mathrm{H}_{2} \mathrm{SO}_{3}$ treated, and homogenised plant material or sediment using a Carlo Erba NA $1500 \mathrm{HCN}$ analyser. The concentrations of acid hydrolysable amino acids were measured in the sediment $\left(\right.$ THAA $\left._{\text {sed }}\right)$ and in the root-rhizomes $\left(\right.$ THAA $\left._{r \mathrm{rth}}\right)$. THAA ${ }_{\text {sed }}$ and THAA $_{\mathrm{rt}+\mathrm{rh}}$ were determined from $1 \mathrm{~cm}^{3}$ sediment and $0.16 \mathrm{~g}$ fresh weight root-rhizomes, respectively, to which $1 \mathrm{ml} 12 \mathrm{~N} \mathrm{HCl}$ was added. The samples were hydrolysed at $105^{\circ} \mathrm{C}$ for $24 \mathrm{~h}$. After hydrolysis, $100 \mu \mathrm{l}$ of the hydrolysate was evaporated in a desiccator under vacuum and subsequently redissolved in $100 \mu \mathrm{l}$ Milli$\mathrm{Q}$ water. This $100 \mu \mathrm{l}$ was evaporated again and finally dissolved in $1 \mathrm{ml}$ Milli-Q water. The THAA was determined as the concentration of dissolved free amino acids measured by high performance liquid chromatography (HPLC, Waters Chromatographic System) 
on $o$-phthaldialdehyde derivatized products (Lindroth \& Mopper 1979).

To determine sediment porosity, 1 sediment core ( $3.2 \mathrm{~cm}$ i.d.) was sampled from both a vegetated and an unvegetated sediment pot from each tank, which resulted in 2 parallel cores from each treatment. The sediment was sectioned into the following depth intervals: $0-2,2-5$, and $5-10 \mathrm{~cm}$. Sediment from parallel cores was pooled for each depth interval. Sediment density was measured as the fresh weight of a known volume of sediment from each depth interval, and the porewater content was determined as the weight loss of sediment dried at $60^{\circ} \mathrm{C}$ to constant weight. Sediment porosity was calculated as the density multiplied by the porewater content.

Porewater pools. Porewater concentrations of ammonium $\left(\mathrm{NH}_{4}{ }^{+}\right)$, urea, dissolved free amino acids (DFAA), and acid hydrolysable amino acids $\left(\right.$ THAA $\left._{\mathrm{pw}}\right)$ were measured in sediment sampled as described above, with the exception that samples from the $0-2 \mathrm{~cm}$ depth interval were pooled from 4 cores to gain enough porewater. The root-rhizomes were removed from both the vegetated and the unvegetated control sediment before porewater extraction to avoid leakage of $\mathrm{NH}_{4}{ }^{+}$and dissolved organic nitrogen from root-rhizomes (Hansen \& Lomstein 1999). The sediment was homogenised, and porewater was obtained by centrifugation at $1000 \times g$ for $6 \mathrm{~min}$. The supernatant was $0.2 \mu \mathrm{m}$ filtered (Sartorius) and frozen for later analysis. Porewater for sulphate analysis was obtained from separate cores, sectioned with root-rhizomes, and frozen for later analysis.

Concentrations of $\mathrm{NH}_{4}{ }^{+}$and urea were determined by the methods described in Bower \& Holm-Hansen (1980) and Price \& Harrison (1987), respectively. The concentration of $\mathrm{SO}_{4}{ }^{-}$was analysed on a Dionex 2010 ion chromatograph. The concentration of $\mathrm{THAA}_{\mathrm{pw}}$ was determined on $1 \mathrm{ml}$ porewater samples as described in a previous section for $T H A A_{\text {sed }}$ and $T H A A_{r 1+r h}$. The concentration of THAA pw $_{\text {was }}$ watained after correction for DFAA.

Sediment microbial processes. Rates of sulphate reduction, urea turnover, nitrogen fixation, and net ammonium production were measured in 3 depth intervals $(0-2,2-5$, and $5-10 \mathrm{~cm})$ in the vegetated and the unvegetated sediment. Urea turnover and sulphate reduction were measured in intact cores $(3.2 \mathrm{~cm}$ i.d.), whereas nitrogen fixation and net ammonium production were measured in homogenised sediment. All incubations were performed in the dark at $24^{\circ} \mathrm{C}$.

Sulphate reduction was measured in duplicate in the vegetated and the unvegetated sediment from each tank by the radiotracer method described in Jørgensen (1978) and Fossing \& Jørgensen (1989). Ten $\mu \mathrm{l}$ carrierfree ${ }^{35} \mathrm{SO}_{4}^{-}\left(19 \mathrm{kBq} \mu^{-1}\right.$, ICN Pharmaceuticals) was injected through silicone-filled side ports in the cores in a horizontal line through the sediment at $1 \mathrm{~cm}$ depth intervals with a resultant activity of $23 \mathrm{kBq} \mathrm{cm}{ }^{-3}$. The sediment cores were incubated for $5 \mathrm{~h}$. The sediment was transferred to $20 \%(\mathrm{w} / \mathrm{v}) \mathrm{ZnAc}$ in a $2: 1 \mathrm{v} / \mathrm{v}$ ratio to stop biological activity and fix the produced ${ }^{35} \mathrm{~S}$ sulphide. The sediment-ZnAc slurry was mixed and frozen for later analysis of ${ }^{35} \mathrm{~S}$ activity. The slurries were distilled as described in Fossing \& Jørgensen (1989). The distillates were mixed with scintillation liquid (Beckman, Ready Safe) and counted in a Packard 1600 TR liquid scintillation analyser.

Urea turnover was determined once in the vegetated and the unvegetated sediment from each tank by the radiotracer method described in Lund \& Blackburn (1989). In each sediment core $10 \mu \mathrm{l}$ of ${ }^{14} \mathrm{C}$-urea tracer (56 Bq $\mathrm{l}^{-1}$, ICN Pharmaceuticals) was injected in a horizontal line at $1 \mathrm{~cm}$ depth interval with a resultant activity of $70 \mathrm{~Bq} \mathrm{~cm}-3$. The urea enrichment due to ${ }^{14} \mathrm{C}$ urea was always $<3 \%$. Cores were incubated as a time course incubation $(0,40$, and $80 \mathrm{~min})$. The sediment was transferred to $2.5 \%(\mathrm{w} / \mathrm{v}) \mathrm{NaOH}$ in a $2: 1 \mathrm{v} / \mathrm{v}$ ratio, to stop biological activity and fix the produced ${ }^{14} \mathrm{CO}_{2}$. The sediment- $\mathrm{NaOH}$ slurry was mixed and frozen for later analysis of ${ }^{14} \mathrm{C}$ activity. The scintillation liquid and the counter were as described for ${ }^{35} \mathrm{SO}_{4}{ }^{-}$. Changes in the porewater concentration of urea were determined in a parallel time course incubation of $1 \mathrm{~cm}^{3}$ sediment with root-rhizomes removed. The urea turnover rate was calculated by the non-steady state Model I described in Lund \& Blackburn (1989).

Nitrogen fixation was measured in triplicate under both oxic and anoxic conditions in the vegetated and the unvegetated sediment from each tank by the acetylene reduction technique (Capone 1993). Sediment slurries were prepared from $10 \mathrm{~cm}^{3}$ sediment including root-rhizomes and $5 \mathrm{ml} 0.45 \mu \mathrm{m}$ filtered (Whatman) seawater in a $125 \mathrm{ml}$ Erlenmeyer flask. At the start of the incubation $10 \%$ of head space was exchanged with acetylene, and the slurries were incubated as a time course incubation $(3,6,9,12$, and $24 \mathrm{~h})$. The concentration of ethylene in samples from head space was measured on a Shimadzu Mini-2 Gas Chromatograph. The ethylene production rate was calculated from the initial linear increase in the concentration of ethylene with time. A ratio of moles ethylene produced to nitrogen fixed of 3.0:1.9 was used to calculate nitrogen fixation from ethylene production. This ratio was obtained in Zostera capricorni sediment from Moreton Bay by O'Donohue et al. (1991).

Net ammonium production was measured in duplicate in the vegetated and the unvegetated sediment from an anoxic time course incubation $(0,9,21,28$, and $42 \mathrm{~h}$ ) of sediment with root-rhizomes. At the end of each incubation, $1 \mathrm{ml} 2 \mathrm{M} \mathrm{KCl}$ was added to the $1 \mathrm{~cm}^{3}$ 
sediment sample, and the mixture was vortexed and extracted for $30 \mathrm{~min}$ at $5^{\circ} \mathrm{C}$, before it was centrifuged at $1000 \times g$ for $6 \mathrm{~min}$. The supernatant was frozen for later analysis. The $\mathrm{KCl}$ extractable $\mathrm{NH}_{4}{ }^{+}\left(\mathrm{NH}_{4}{ }^{+} \mathrm{KCl}\right)$ was analysed as described for porewater $\mathrm{NH}_{4}{ }^{+}$. The net ammonium production rate was calculated from the change in concentration with time.

Processes associated with roots and rhizomes. Rates of urea turnover, sulphate reduction, and nitrogen fixation associated with root-rhizomes were in principle measured as described for the respective processes in the sediment. Root-rhizomes $(\sim 0.1 \mathrm{~g}$ fresh weight) were incubated in $5 \mathrm{ml} 0.2 \mu \mathrm{m}$ filtered (Sartorius) porewater. Glucose and acetate were added as substrates to the porewater to a final concentration of $0.8 \mathrm{mM}$ together with $1 \mathrm{mg}$ Poly (A) per $5 \mathrm{ml}$. Poly (A) is a polymer of the nucleotide adenosine, which stimulate the turnover of urea (Therkildsen et al. 1996). Root-rhizomes from the 10 and $50 \%$ tanks were incubated under both oxic and anoxic conditions. Samples were incubated in the dark on a shaking table at $24^{\circ} \mathrm{C}$.

Rates of urea turnover and sulphate reduction were measured in triplicate by the methods described for the sediment incubations except that $5 \mu$ of tracer were added with a resultant activity of $56 \mathrm{~Bq} \mathrm{~m}^{-1}\left({ }^{14} \mathrm{C}\right.$-urea) and $19 \mathrm{kBq} \mathrm{ml}{ }^{-1}\left({ }^{35} \mathrm{SO}_{4}{ }^{-}\right)$. Urea turnover was measured in a time course incubation $(0,30$, and $60 \mathrm{~min})$. Samples without tracer were incubated in parallel to follow the change in the concentration of urea with time. Sulphate reduction was measured in an end point incubation $(4 \mathrm{~h})$. The incubations were stopped by the addition of $2.5 \mathrm{ml} 2.5 \%(\mathrm{w} / \mathrm{v}) \mathrm{NaOH}$ (urea turnover) and $20 \%(\mathrm{w} / \mathrm{v}) \mathrm{ZnAc}$ (sulphate reduction). Nitrogen fixation was measured in 5 parallel incubations by the methods described for the sediment incubations.

Statistical analysis. Plant characteristics (except carbon and nitrogen contents), sediment processes, and root-rhizome processes are presented as mean values \pm standard error (SE) of the mean. A 2-tailed Student's $t$-test was used for comparison of data.

\section{RESULTS}

\section{Plant characteristics}

After $5 \mathrm{wk}$ of incubation the root-rhizome biomass of Zostera capricorni was $87 \mathrm{~g} \mathrm{dry} \mathrm{wt} \mathrm{m}^{-2}$ in the $10 \%$ light treatment and $239 \mathrm{~g} \mathrm{dry} \mathrm{wt} \mathrm{\textrm {m } ^ { - 2 }}$ in the $50 \%$ light treatment (Table 1). However, the vertical distribution of root-rhizome biomass within the upper $10 \mathrm{~cm}$ of the sediment was similar in the 2 treatments: $\sim 70 \%$ in the

Table 1. Characteristics of Zostera capricorni after $5 \mathrm{wk}$ incubation at light intensities corresponding to 10 and $50 \%$ of the incident light. p-values are from a comparison of 10 and $50 \%$ data. Values in parentheses are standard errors of mean ( $n=2)$. ${ }^{*}$ Parameters that are significantly different $(\mathrm{p}<0.05)$ in the 10 and $50 \%$ treatment

\begin{tabular}{|c|c|c|c|c|}
\hline & & \multicolumn{2}{|c|}{ Treatment } & \multirow[t]{2}{*}{$\mathrm{p}$} \\
\hline & & $10 \%$ & $50 \%$ & \\
\hline \multicolumn{5}{|l|}{ Morphology } \\
\hline \multicolumn{2}{|c|}{ Maximum canopy height $(\mathrm{cm})$} & $18.5(0.5)$ & $12.0(0.3)$ & $<0.01^{*}$ \\
\hline \multicolumn{2}{|c|}{ Shoot density (shoots $\mathrm{m}^{-2}$ ) } & $1413(88)$ & $3850(450)$ & $0.03^{*}$ \\
\hline \multicolumn{2}{|c|}{ Root-rhizome vol. $\left(\text { vol }_{\mathrm{rt}-\mathrm{rh}} / \mathrm{vol}_{\text {sed }} \times 100 \%\right)^{\mathrm{a}}$} & $0.35(0.02)$ & $0.95(0.06)$ & $0.01^{*}$ \\
\hline \multicolumn{5}{|l|}{ Biomass } \\
\hline \multirow[t]{2}{*}{ Leaves } & $\left(\mathrm{g} \mathrm{dw} \mathrm{m}^{-2}\right)$ & $13.2(0.9)$ & $30.5(3.4)$ & $0.03^{*}$ \\
\hline & $\left(\mathrm{mg} \mathrm{dw} \mathrm{shoot}{ }^{-1}\right)$ & $9.3(0.1)$ & $8.1(1.8)$ & 0.57 \\
\hline \multirow[t]{2}{*}{ Roots-rhizomes } & $\left(\mathrm{g} \mathrm{dw} \mathrm{m}^{-2}\right)$ & $87(4)$ & $239(16)$ & $0.01^{*}$ \\
\hline & $\left(\mathrm{mg} \mathrm{dw} \mathrm{shoot}^{-1}\right)$ & 62 (1) & $63(11)$ & 0.90 \\
\hline \multirow{2}{*}{ Total } & $\left(\mathrm{g} \mathrm{dw} \mathrm{m} \mathrm{m}^{-2}\right)$ & $100(5)$ & $269(19)$ & $0.01^{*}$ \\
\hline & $\left(\mathrm{mg} \mathrm{dw}\right.$ shoot $\left.{ }^{-1}\right)$ & 71 & 71 (13) & 0.90 \\
\hline \multicolumn{5}{|c|}{ Growth and turnover } \\
\hline \multirow[t]{2}{*}{ Leaf production } & $\left(g \mathrm{dw} \mathrm{m}^{-2} \mathrm{~d}^{-1}\right)$ & $0.69(0.11)$ & $1.70(0.11)$ & $0.02^{*}$ \\
\hline & $\left(\mathrm{mg} \mathrm{dw}\right.$ shoot $\left.^{-1} \mathrm{~d}^{-1}\right)$ & $0.48(0.05)$ & $0.45(0.08)$ & 0.78 \\
\hline Leaf turnover & (d) & $20(2)$ & $18(1)$ & 0.48 \\
\hline \multicolumn{5}{|c|}{ Carbon and nitrogen content } \\
\hline \multirow[t]{3}{*}{ Leaves } & $(\% \mathrm{C}$ of $\mathrm{dw})$ & 36.3 & 33.0 & \\
\hline & $(\% \mathrm{~N}$ of $\mathrm{dw})$ & 2.85 & 2.17 & \\
\hline & (molar C:N ratio) & 14.8 & 17.7 & \\
\hline \multirow{3}{*}{ Roots-rhizomes } & $(\% \mathrm{C}$ of $\mathrm{dw})$ & 25.0 & 23.1 & \\
\hline & $(\% \mathrm{~N}$ of $\mathrm{dw})$ & 0.84 & 0.55 & \\
\hline & (molar C:N ratio) & 34.8 & 48.7 & \\
\hline
\end{tabular}


$0-2 \mathrm{~cm}$ stratum, $\sim 20 \%$ in the $2-5 \mathrm{~cm}$ stratum, and $-10 \%$ in the $5-10 \mathrm{~cm}$ stratum. Also, leaf biomass, shoot density, and leaf production of $Z$. capricorni were 2.5-fold higher when plants were exposed to $50 \%$ rather than $10 \%$ of the incident light (Table 1). The maximum canopy height was $12.0 \mathrm{~cm}$ in the $50 \%$ light treatment, which was significantly lower than the $18.5 \mathrm{~cm}$ measured in the $10 \%$ light treatment. The shoot-specific leaf and root-rhizome biomass and leaf production, and the leaf turnover rate did not differ significantly with light exposure (Table 1). The organic carbon and nitrogen contents were lower in the $50 \%$ than in the $10 \%$ treatment for both leaves and root-rhizomes, and the molar C:N ratio was higher in the $50 \%$ than in the $10 \%$ treatment for both leaves and rootrhizomes (Table 1).

\section{Sediment pools}

Sediment porewater concentrations of $\mathrm{NH}_{4}{ }^{+}$, urea, DFAA, and THAA $\mathrm{pw}_{\mathrm{p}}$ in the unvegetated control sediment are presented as a mean of the results obtained in the 50 and $10 \%$ light treatments, as no consistent differences were noted. The concentration of $\mathrm{NH}_{4}{ }^{+}$was higher in the unvegetated than in the vegetated sediment (Fig. 1a). The concentration of $\mathrm{NH}_{4}{ }^{+}$decreased with depth in the vegetated sediments from $\sim 25 \mu \mathrm{M}$ in the upper $2 \mathrm{~cm}$ to $\sim 15 \mu \mathrm{M}$ in the $5-10 \mathrm{~cm}$ depth stratum. In the unvegetated sediment, the $\mathrm{NH}_{4}{ }^{+}$concentration increased from $23 \mu \mathrm{M}$ in the upper $2 \mathrm{~cm}$ to $69 \mu \mathrm{M}$ in the $5-10 \mathrm{~cm}$ depth stratum. In all treatments there was a maximum in the concentration of urea in the 2-5 cm depth interval of $\sim 9 \mu \mathrm{M}$ in the vegetated sediment and $17 \mu \mathrm{M}$ in the unvegetated sediment. There was an almost linear decrease in the concentration of DFAA with depth in both the vegetated and unvegetated sediments. The highest DFAA concentration $(76 \mu \mathrm{M})$ was obtained in the $0-2 \mathrm{~cm}$ depth interval in the $50 \%$ treatment of the vegetated sediment (Fig. 1c). The concentration of THAA $\mathrm{pw}_{\mathrm{p}}$ was lowest in the $0-2 \mathrm{~cm}$ depth interval in both the vegetated and unvegetated sediment. The highest $\mathrm{THAA}_{\mathrm{pw}}$ concentration $(34 \mu \mathrm{M})$ was obtained in the $2-5 \mathrm{~cm}$ depth interval in the $50 \%$ treatment of the vegetated sediment (Fig. 1d). The depth-integrated pool of THAA TH was $\sim 1 \mathrm{mmol} \mathrm{m}^{-2}$ in both the vegetated and unvegetated sediment, and constituted $<0.1 \%$ of THAA $_{\text {sed }}$.
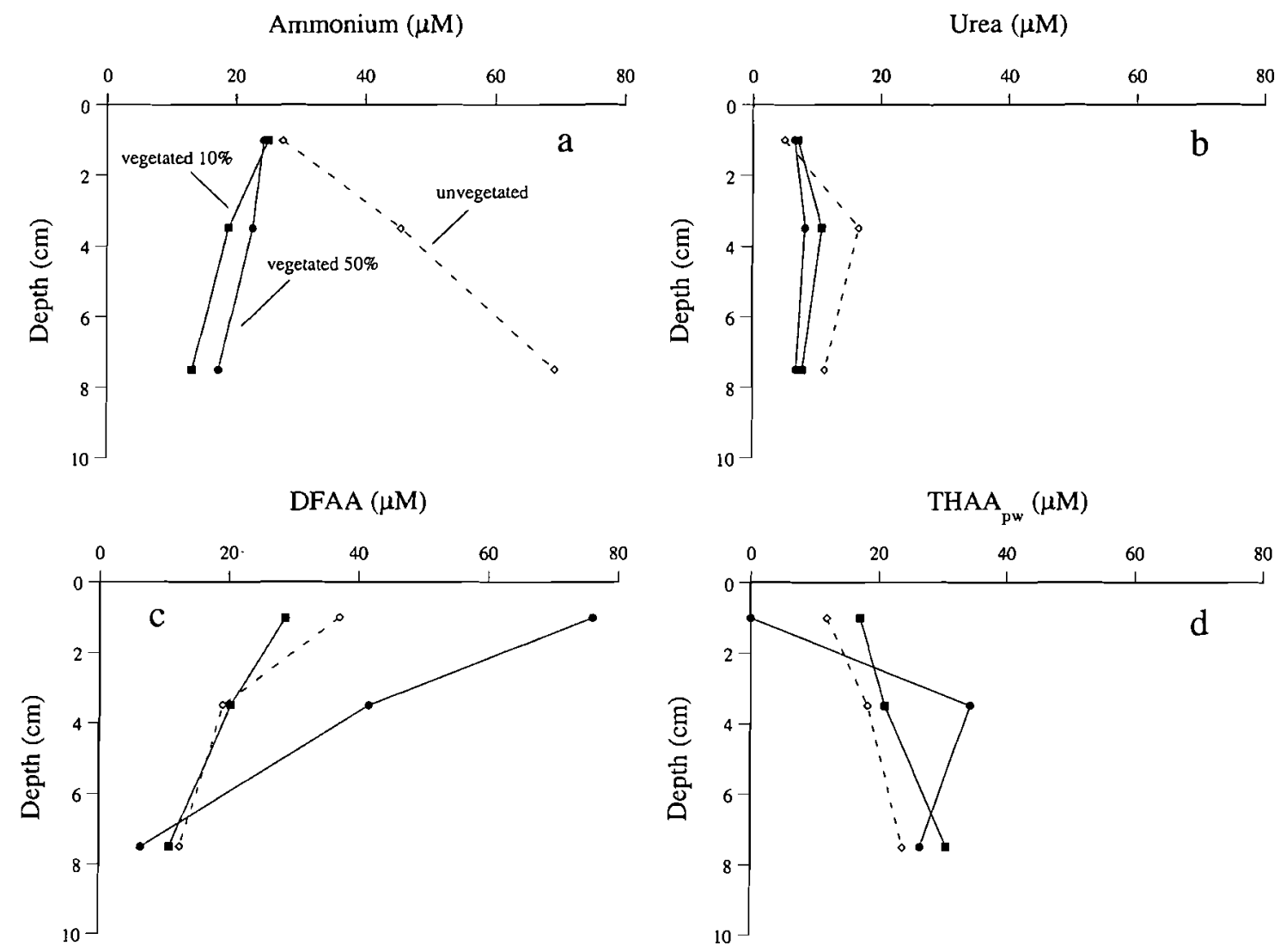

Fig. 1. Profiles of porewater concentrations of (a) $\mathrm{NH}_{4}{ }^{+}$, (b) urea, (c) DFAA, and (d) THAA pw $_{\text {in }}$ vegetated sediment exposed to $50 \%(\bullet)$ and $10 \%(\bullet)$ of incident light and in unvegetated sediment $(\diamond)$ 


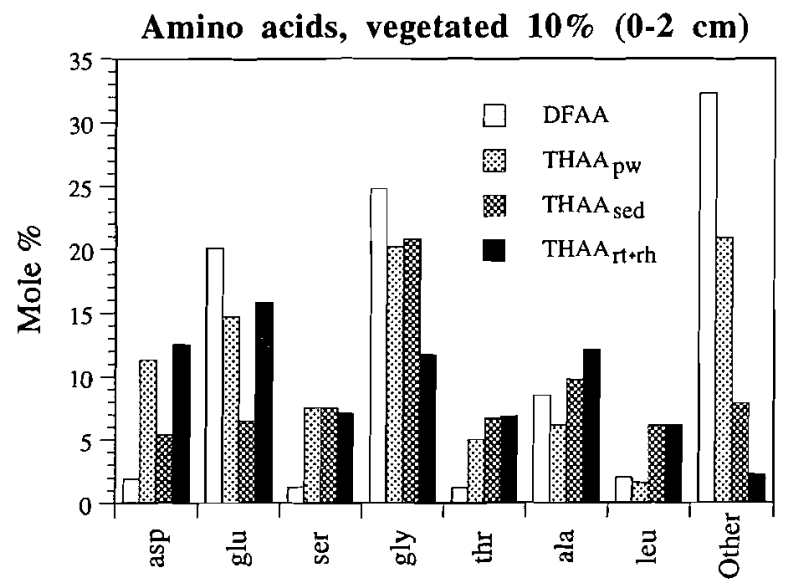

Fig. 2. Molar composition of amino acids in DFAA, THAA pw $_{\text {, }}$ THAA $_{\text {sed }}$ and THAA $\mathrm{rt}_{\mathrm{r}+\mathrm{r}}$ in the upper $2 \mathrm{~cm}$ of the vegetated sediment adapted to $10 \%$ of the incident light. Other: unidentified amino acids

The depth-integrated pools of THAA ${ }_{\text {sed }}$ and THAA $_{\mathrm{rt}+\mathrm{rh}}$ in the upper $10 \mathrm{~cm}$ of the vegetated sediment were 1282 and $42 \mathrm{mmol} \mathrm{m}^{-2}$, respectively, in the $50 \%$ treatment and 1271 and $14 \mathrm{mmol} \mathrm{m}^{-2}$, respectively, in the $10 \%$ treatment. The $\mathrm{THAA}_{\mathrm{rt}+\mathrm{rh}}$ concentrations were high, with a maximum of $62 \mathrm{mM}$.

The molar composition of DFAA, THAA ${ }_{\mathrm{pw}}$, THAA $_{\text {sed }}$, and THAA $_{\mathrm{rt}+\mathrm{rh}}$ in the upper $2 \mathrm{~cm}$ of the vegetated sediment exposed to $10 \%$ of the incident light is presented in Fig. 2. Glutamic acid and glycine were the dominant protein amino acids. Histidine, arginine, tyrosine, methionine, valine, phenylalanine, iso-leucine, and lysine each accounted for less than $6 \%$ of the amino acid pools (data not shown). Unidentified amino acids accounted for $32,21,8$, and $2 \%$ of DFAA, THAA $\mathrm{THAA}_{\text {sed }}$ and $\mathrm{THAA}_{\mathrm{rt}+\mathrm{rh}}$, respectively. A similar molar composition of amino acids was obtained in the other depth intervals for both the vegetated and the unvegetated sediment at both light levels (data not shown).

The molar C:N ratio of total sediment organic matter did not show any significant difference between the vegetated and the unvegetated sediment or between the 2 light treatments, and there was no marked change with depth (data not shown). The average molar C:N ratio in the total sediment organic matter was $14.1 \pm 0.4 \mathrm{~mol} \mathrm{~mol}^{-1}(\mathrm{n}=12)$. The average sediment TOC and TON contents were $70.0 \pm 4.6 \mathrm{~mol} \mathrm{C}$ $\mathrm{m}^{-2}(\mathrm{n}=12)$ and $4.8 \pm 0.4 \mathrm{~mol} \mathrm{~N} \mathrm{~m} \mathrm{~N}^{-2}(\mathrm{n}=12)$, respectively.

\section{Sediment microbial processes}

Sediment processes in the unvegetated sediment are presented as a mean of the results obtained in the 50 and $10 \%$ light treatment, as there was no significant difference between results obtained in the 2 treatments.

The rate of nitrogen fixation decreased with depth from 94,45 , and $15 \mathrm{nmol} \mathrm{N} \mathrm{cm}{ }^{-3} \mathrm{~d}^{-1}$ in the upper $2 \mathrm{~cm}$ strata of the vegetated $(50 \%)$, the vegetated $(10 \%)$, and the unvegetated sediment, respectively, to 16,12 , and $4 \mathrm{nmol} \mathrm{N} \mathrm{cm}^{-3} \mathrm{~d}^{-1}$ in the $5-10 \mathrm{~cm}$ depth stratum (Fig. 3a). Nitrogen fixation rates were significantly higher in the vegetated than in the unvegetated sediment at all depths $(p<0.01)$. Further, the rate of nitrogen fixation in the main root zone (rhizosphere: $0-5 \mathrm{~cm}$ ) was significantly higher in the $50 \%$ than in the $10 \%$ light treatment $(\mathrm{p}<0.01)$. The depth-integrated rates were $5.4,2.6$, and $0.7 \mathrm{mmol} \mathrm{N} \mathrm{m} \mathrm{N}^{-2} \mathrm{~d}^{-1}$ in the vegetated $(50 \%)$, the vegetated $(10 \%)$, and the unvegetated sediment, respectively (Fig. 4). The nitrogen fixation rates presented are mean values of rates obtained under oxic and anoxic conditions, as these rates were not significantly different $(p>0.19)$.

The sulphate reduction rate in the vegetated sediments decreased with depth from 408 and $273 \mathrm{nmol}$ $\mathrm{cm}^{-3} \mathrm{~d}^{-1}$ in the upper $2 \mathrm{~cm}$ of the 50 and $10 \%$ light treatment, respectively, to 157 and $135 \mathrm{nmol} \mathrm{cm} \mathrm{cm}^{-3} \mathrm{~d}^{-1}$ in the $5-10 \mathrm{~cm}$ stratum (Fig. $3 \mathrm{~b}$ ). In the unvegetated sediment there was a maximum of $254 \mathrm{nmol} \mathrm{cm}{ }^{-3} \mathrm{~d}^{-1}$ in the $2-5 \mathrm{~cm}$ depth interval of the unvegetated sediment. The sulphate reduction rate was significantly higher in the vegetated than in the unvegetated sediment in the upper $2 \mathrm{~cm}(p<0.03)$. In the vegetated sediment the sulphate reduction rate was higher, although not significantly, in the $50 \%$ than in the $10 \%$ light treatment at all depths $(p>0.18)$. Depth-integrated rates were $26.6,19.2$, and $18.1 \mathrm{mmol} \mathrm{m}^{-2} \mathrm{~d}^{-1}$ in the vegetated $(50 \%)$, the vegetated $(10 \%)$, and the unvegetated sediment, respectively (Fig. 4).

The urea turnover rate was highest in the upper $2 \mathrm{~cm}$ of the sediment in all treatments (Fig. 3c). The urea turnover rate was higher, although not significantly, in the vegetated than in the unvegetated sediment in the upper $2 \mathrm{~cm}(\mathrm{p}>0.09)$. The depth-integrated rates were $18.5,17.2$, and $15.2 \mathrm{mmol} \mathrm{N} \mathrm{m}^{-2} \mathrm{~d}^{-1}$ in the vegetated $(50 \%)$, the vegetated $(10 \%)$, and the unvegetated sediment, respectively (Fig. 4).

The net ammonium production was not significantly different from zero at any depths in any treatments ( $p>$ 0.07 , data not shown).

\section{Processes associated with roots and rhizomes}

The rates of nitrogen fixation, sulphate reduction, and urea turnover associated with root-rhizomes were up to 8669,8157 , and $462 \mathrm{nmol} \mathrm{g}^{-1}$ dry wt root-rhizome $\mathrm{d}^{-1}$, respectively, and could potentially account for 39 , 
4 , and $1 \%$ of the respective depth-integrated rates in the sediment (Table 2). The rates obtained with rootrhizomes from the $50 \%$ light treatment were not significantly different from the rates obtained with root-
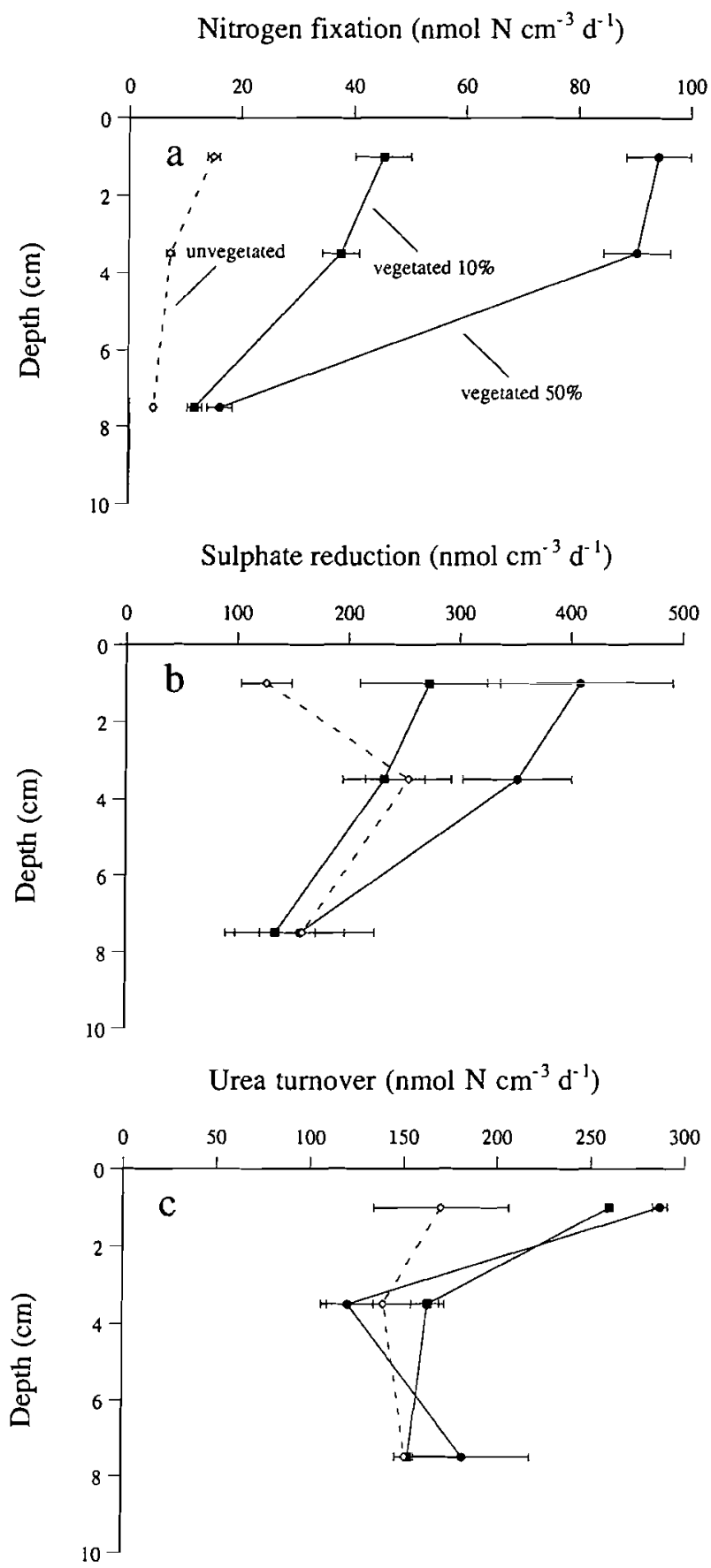

Fig. 3. Sediment profiles for rates of (a) nitrogen fixation, (b) sulphate reduction, and (c) urea turnover in vegetated sediment exposed to $50 \%(\bullet)$ and $10 \%$ (a) of incident light and in unvegetated sediment (0). Error bars represent standard errors of means $(n=6$ for nitrogen fixation, $n=4$ for sulfate reduction, and $\mathrm{n}=2$ for urea turnover; $\mathrm{n}$ was $12,8,4$, respectively, in the unvegetated sediment) rhizomes from the $10 \%$ light treatment $(p>0.05)$. The nitrogen fixation rates associated with root-rhizomes were significantly higher under oxic than under anoxic conditions $(p<0.01)$. However, the rates of sulphate reduction and urea turnover were not significantly different under oxic than under anoxic conditions $(p>$ 0.28 , data not shown), and are, therefore, presented as the mean of the results from the 2 treatments.

\section{DISCUSSION}

\section{Plant response to different light irradiances}

The estimated leaf turnover time of 18 to $20 \mathrm{~d}$ indicates that Zostera capricorni was able to adapt to the 2 light irradiances, of 50 and $10 \%$ of incident light, within the 5 wk tank incubation (Table 1). Adaptation to the low-light environment was also indicated from the plant characteristics; as leaf and root-rhizome biomass, shoot density, and leaf productivity were significantly lower and the maximum canopy height significantly higher in the $10 \%$ than in the $50 \%$ light treatment $(p<0.05)$. These changes in plant characteristics seem to be a general adaptation to low light in seagrasses (Backman \& Barilotti 1976, Dennison \& Alberte 1985, Olesen \& Sand-Jensen 1993, Abal et al. 1994, Czerny \& Dunton 1995, Philippart 1995, Short et al. 1995). There was no significant difference in the shoot-specific biomass or the shoot-specific leaf production in the 50 and $10 \%$ light treatment ( $p>0.55$ ). Hence, $Z$. capricorni adapted to the 2 light irradiances through changes in the shoot density and morphology rather than through changes of the shoot-specific biomass or productivity. However, we can not exclude that a longer incubation period could have lowered shoot-specific growth in the $10 \%$ light treatment, as irradiance in this treatment was close to the minimum light requirement of seagrasses (Duarte 1991, Dennison et al. 1993). In shorter periods with severe light limitation, seagrasses can survive by mobilisation of carbon reserves stored in root-rhizomes (Alcoverro et al. 1999).

\section{Sediment microbial processes \\ Nitrogen fixation}

The sediment nitrogen fixation rates obtained in the present study were high, but within the range of rates encountered in other tropical and subtropical seagrass meadows (Patriquin \& Knowles 1972, Capone \& Taylor 1980, O'Donohue et al. 1991, Moriarty \& O'Donohue 1993), which are often much higher than rates from 

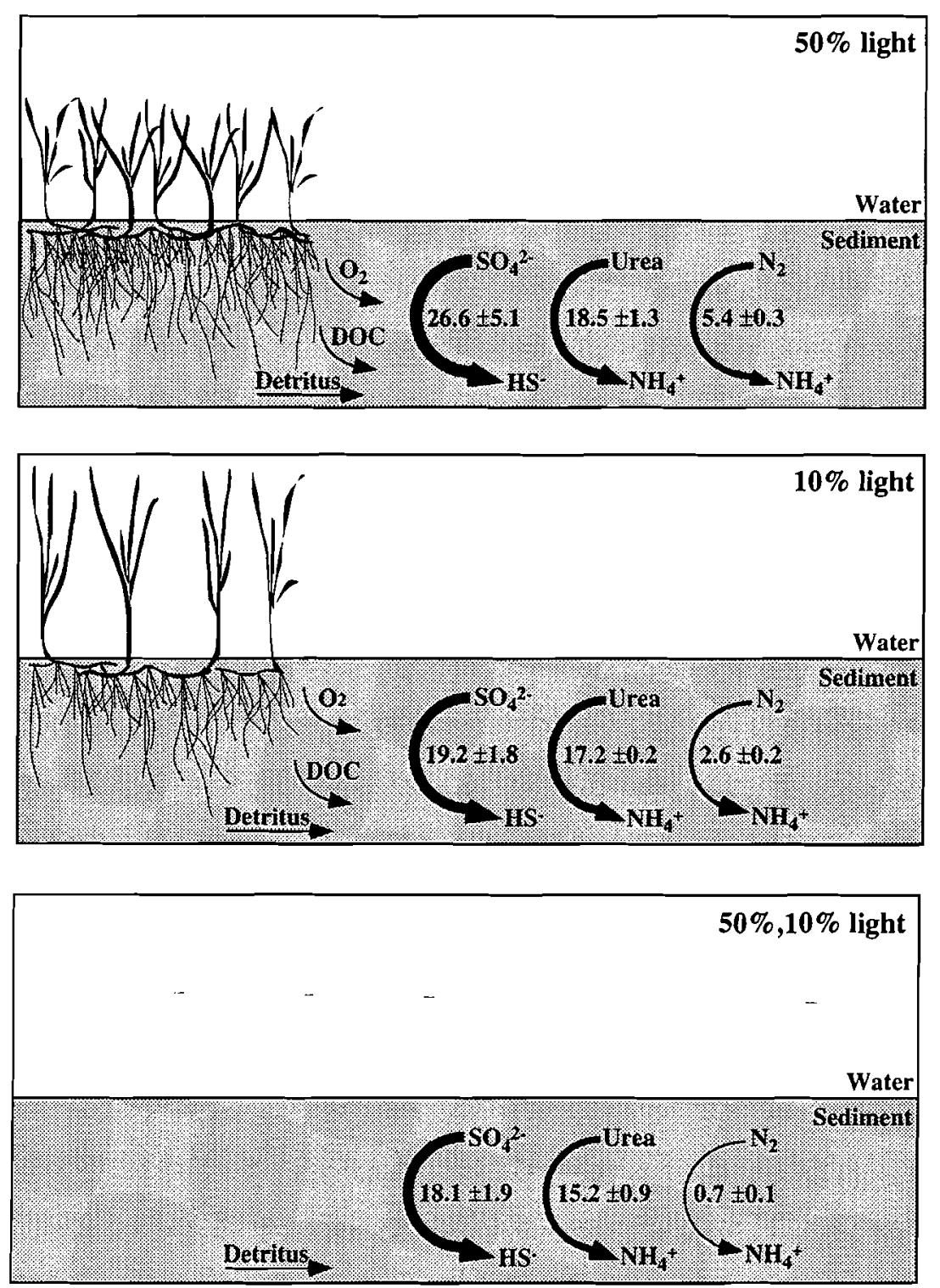

Fig. 4. Depth-integrated, 0 to $10 \mathrm{~cm}$, sediment rates of nitrogen fixation, sulphate reduction, and urea turnover given in mmol $\mathrm{m}^{-2}$ $\mathrm{d}^{-1}$. Upper and middle box present rates from the vegetated sediments that received 50 and $10 \%$ of the incident light, respectively, and the lower box present values from the unvegetated sediment. The \pm values represents standard errors of means $(\mathrm{n}=$ 6 for nitrogen fixation, $\mathrm{n}=4$ for sulphate reduction, and $\mathrm{n}=2$ for urea turnover; $\mathrm{n}$ was $12,8,4$, respectively, in the unvegetated sediment)

temperate seagrass meadows (Capone \& Budin 1982, Welsh et al. 1996, McGlathery et al. 1998). The nitrogen fixation rates obtained in this study were higher in the vegetated than in the unvegetated sediment due to a stimulation of the nitrogen fixation in the rhizosphere, 0-5 cm (Figs. 3a \& 4). A rapid transfer of fixed nitrogen from the rhizosphere to the plant has been demonstrated for Zostera capricorni and Zostera marina (Capone 1988, O'Donohue et al. 1991). O'Donohue et al. (1991) estimated that $50 \%$ of the nitrogen fixed in the rhizosphere of a $Z$. capricorni sediment was transferred to the leaves within $6 \mathrm{~h}$. In the present study, nitrogen fixation in the rhizosphere could potentially supply $\sim 90 \%$ of the nitrogen requirement for growth, if $50 \%$ of the fixed nitrogen was transferred to the plant. The nitrogen requirement for growth was estimated from leaf and root-rhizome growth and the average nitrogen content in the leaves and the rootrhizomes. The root-rhizome growth was assumed to be 89 and $21 \%$ of the leaf growth in the 50 and $10 \%$ light 
Table 2. Root-rhizome associated process rates and their contribution to the area sediment rates in the Zostera capricorni bed. Rt-rh: roots-rhizomes. Values in parentheses are standard errors of mean: $n=6$ for sulphate reduction and urea turnover, $n=5$ for nitrogen fixation

\begin{tabular}{|c|c|c|}
\hline & $10 \%$ & $50 \%$ \\
\hline \multicolumn{3}{|l|}{ Nitrogen fixation, aerobic } \\
\hline Rates per weight $\mathrm{rt}-\mathrm{rh}\left(\mathrm{nmol} \mathrm{g}^{-1} \mathrm{dw} \mathrm{d}^{-1}\right)$ & $7300(683)$ & $8669(979)$ \\
\hline Rates per volume rt-rh $\left(\mathrm{nmol} \mathrm{cm} \mathrm{cm}^{-3} \mathrm{~d}^{-1}\right)$ & $1825(171)$ & $2173(245)$ \\
\hline Rt-rh contribution to areal sediment rates $(\%)^{a}$ & $27.8(2.6)$ & $39.0(4.4)$ \\
\hline \multicolumn{3}{|l|}{ Nitrogen fixation, anaerobic } \\
\hline Rates per weight $\mathrm{rt}-\mathrm{rh}\left(\mathrm{nmol} \mathrm{g} \mathrm{g}^{-1} \mathrm{dw} \mathrm{d}^{-1}\right)$ & $3106(214)$ & $3779(337)$ \\
\hline Rates per volume rt-rh $\left(\mathrm{nmol} \mathrm{cm}-3 \mathrm{~d}^{-1}\right)$ & $777(53)$ & $945(84)$ \\
\hline Rt-rh contribution to areal sediment rates $(\%)^{\mathrm{a}}$ & $11.8(0.8)$ & $17.0(1.5)$ \\
\hline \multicolumn{3}{|l|}{ Sulphate reduction } \\
\hline Rates per weight rt-rh $\left(\mathrm{nmol} \mathrm{g}^{-1} \mathrm{dw} \mathrm{d}^{-1}\right)$ & $8157(2165)$ & $4641(1681)$ \\
\hline Rates per volume rt-rh $\left(\mathrm{nmol} \mathrm{cm} \mathrm{c}^{-3} \mathrm{~d}^{-1}\right)$ & 2039 & $1160(420)$ \\
\hline Rt-rh contribution to areal sediment rates $(\%)^{\mathrm{a}}$ & $4.2(1.1)$ & $4.2(1.5)$ \\
\hline \multicolumn{3}{|l|}{ Urea turnover } \\
\hline Rates per weight $\mathrm{rt}-\mathrm{rh}\left(\mathrm{nmol} \mathrm{g} \mathrm{g}^{-1} \mathrm{dw} \mathrm{d}^{-1}\right)$ & $92(93)$ & $462(105)$ \\
\hline Rates per volume rt-rh $\left(\mathrm{nmol} \mathrm{cm} \mathrm{c}^{-3} \mathrm{~d}^{-1}\right)$ & $23(23)$ & $115(26)$ \\
\hline Rt-rh contribution to areal sediment rates $(\%)^{a}$ & $0.1(0.1)$ & $0.6(0.1)$ \\
\hline
\end{tabular}

treatment, respectively, as found for $Z$. capricorni adapted to 50 and $15 \%$ of incident light (Abal et al. 1994). If the difference between the depth-integrated nitrogen fixation rates in the vegetated and the unvegetated sediment is assumed to represent a potential nitrogen uptake by the plants, this could supply $\sim 140 \%$ of the nitrogen needed for growth of $Z$. capricorni. However, part of this estimated potential nitrogen uptake may be incorporated in bacteria instead of plants, since bacterial activity was higher in the vegetated than the unvegetated sediment. Based on the estimates above, we suggest that nitrogen fixed in the rhizosphere was an important nitrogen source for $Z$. capricorni.

The nitrogen fixation rates obtained in the incubation of the rinsed Zostera capricorni root-rhizomes were comparable to rates of nitrogen fixation obtained from incubations of root-rhizomes of other seagrasses (Capone \& Taylor 1980, Capone \& Budin 1982, Smith \& Hayasaka 1982a,b). The nitrogen fixation rate associated with the $Z$. capricorni root-rhizomes were up to 70 -fold higher than the average nitrogen fixation rate in the vegetated sediment and accounted for up to $39 \%$ of the nitrogen fixation in the vegetated sediment (Table 2). Other studies have demonstrated that nitrogen fixation associated with root-rhizomes can account for a significant proportion of the total nitrogen fixation in Z. capricorni and Syringodium isotifolium sediments (O'Donohue et al. 1991, Moriarty \& O'Donohue 1993). In the present study nitrogen fixation associated with root-rhizomes could potentially supply a substantial part $(21$ to $65 \%$ ) of the nitrogen required for growth in $Z$. capricorn as also demonstrated by $\mathrm{O}^{\prime}$ Donohue et al. (1991).

The nitrogen fixation rates associated with root-rhizomes were significantly higher under oxic than under anoxic conditions ( $p<0.01$, Table 2 ) a result also found for other seagrasses (Smith \& Hayasaka 1982a,b). This seems to be an adaptation to oxic conditions at the surface of root-rhizomes caused by leakage of oxygen from root-rhizomes (Sand-Jensen et al. 1982, Smith et al. 1984, Thursby 1984, Pedersen et al. 1998, 1999, Connell et al. 1999). Root-rhizomes are an important site for nutrient uptake, and leakage of oxygen could be a secondary effect of the nutrient uptake. However, leakage of oxygen in an anoxic environment could also be a protection of root-rhizomes against reduced phytotoxins like sulphide (Penhale \& Wetzel 1983, Goodman et al. 1995, Pedersen et al. 1998).

In the present study, the nitrogen fixation rates associated with root-rhizomes were potential rates, as the root-rhizomes were incubated in substrate enriched porewater. However, the root-rhizomes of seagrasses release dissolved organic carbon (Wetzel \& Penhale 1979, Moriarty et al. 1986), and the microorganisms associated with the root-rhizome complex are therefore exposed to higher substrate concentrations than microorganisms in unvegetated sediments. Leakage of photosynthates from root-rhizomes has been suggested to be an important carbon source for nitrogen 
fixing bacteria, as light has been shown to stimulate nitrogen fixation in the rhizosphere of seagrasses (Capone 1988, O'Donohue et al. 1991, Welsh et al. 1996, 1997, McGlathery et al. 1998). In addition, nitrogen fixing bacteria have been demonstrated in high numbers both on the surface and intercellularly in roots and rhizomes of seagrasses, and the seasonal variation in the no. of bacteria attached to rootrhizomes followed the productivity of the seagrasses (Smith \& Hayasaka 1982b, Schmidt \& Hayasaka 1985, Shieh et al. 1989, Glazebrook et al. 1996). These studies indicated a close nutritional association between bacteria and seagrasses, which may be of mutual advantad especially in oligotrophic systems.

\section{Sulphate reduction}

Sulphate reduction rates in the Zostera capricorni sediment were comparable to rates measured in other seagrass sediments (Pollard \& Moriarty 1991, Blackburn et al. 1994, Isaksen \& Finster 1996, Welsh et al. 1996, Holmer \& Nielsen 1997, Blaabjerg et al. 1998). The sulphate reduction rates obtained here were higher in the vegetated than in the unvegetated sediment due to elevated rates in the rhizosphere (Figs. 3b \& 4), a result also found in other seagrass sediments (Pollard \& Moriarty 1991, Isaksen \& Finster 1996. Holmer \& Nielsen 1997). Sulphate reduction in seagrass sediments is stimulated by light, which suggests that sulphate reduction in seagrass sediments, like nitrogen fixation, is stimulated by leakage of photosynthates from root-rhizomes (Blaabjerg et al. 1998). We estimated, from the difference between the depthintegrated sulphate reduction rate in the vegetated and the unvegetated sediments, the leakage of organic carbon from the root-rhizomes to be 8 to $18 \%$ of the carbon fixed by $Z$. capricorni. The total amount of fixed carbon was estimated as the carbon needed for plant growth (based on carbon content and growth data from this study and Abal et al. 1994) plus the estimated leakage from root-rhizomes. Direct measurements of carbon loss due to leakage from root-rhizomes of Zostera marina, Halodule wrightii, and Thalassia testudinum accounted for $\sim 1$ to $17 \%$ of the carbon fixed (Penhale \& Smith 1977, Wetzel \& Penhale 1979, Moriarty et al. 1986, Blaabjerg et al. 1998).

The sulphate reduction rates associated with the rinsed Zostera capricorni root-rhizomes were up to 11 -fold higher than the average sulphate reduction rate in the vegetated sediment and accounted for $4 \%$ of the total sulphate reduction in the vegetated sediment (Table 2). High sulphate reduction rates associated with root-rhizomes were also demonstrated in a study of Zostera marina (Blaabjerg \& Finster 1998). In addition, Blaabjerg \& Finster (1998) demonstrated a high tolerance of root-rhizome associated sulphate reducing bacteria to oxygen as an adaptation to oxygen leakage from roots-rhizomes. The sulphate reducers associated with the rootrhizomes in the present study must also have been tolerant to oxygen, as sulphate reduction rates were not significantly different under oxic and anoxic conditions ( $p>0.28)$.

\section{Urea turnover and net ammonium production}

The urea turnover rate was $\sim 1.5$-fold higher in the vegetated sediment when compared to the unvegetated sediment within the upper $2 \mathrm{~cm}$ of the sediment, which indicates that the turnover of urea was stimulated by the presence of root-rhizomes (Fig. 3c). However, the urea turnover rate associated with rootrhizomes was lower than the urea turnover rate in the sediment (Table 2). This indicates that the bacteria responsible for the turnover of urea were only loosely associated to the root-rhizomes, and therefore poorly represented in the incubation of rinsed root-rhizomes. The urea turnover rate and the gross ammonium production rate in Zostera capricorni sediment in Moreton Bay obtained in the present study and by Boon et al. (1986), respectively, indicate that more than half of the gross ammonium production could be due to the turnover of urea. We therefore suggest that urea is an important intermediate in the nitrogen cycle in this area.

There was no net production of ammonium in the Zostera capricorni sediment, contrary to what has been found in other seagrass sediments (Iizumi et al. 1982, Caffrey \& Kemp 1990, Blackburn et al. 1994). Boon et al. (1986) also found low rates of net ammonium production in Z. capricorni sediments of Moreton Bay, despite the fact that rates of gross ammonium production were high. Consequently, the low net ammonium production indicated an efficient uptake and a rapid turnover of $\mathrm{NH}_{4}{ }^{+}$as expected for an oligotrophic and presumably nitrogen limited system.

\section{Amino acids in the sediment}

The acid hydrolysable amino acids accounted for $-30 \%$ of TON in the Zostera capricorni sediment, which is comparable to the proportions $(53 \%)$ found in an unvegetated sediment (Lomstein et al. 1998). The depthintegrated pools of acid hydrolysable amino acids in the sediment $\left(\mathrm{THAA}_{\text {sed }}\right.$ ) and in the root-rhizomes $\left(\right.$ THAA $\left._{\mathrm{rt}+\mathrm{rh}}\right)$ were 3 and 1 order of magnitude higher, respectively, than the depth-integrated pool of acid hydrolysable amino acids in the porewater $\left(\right.$ THAA $\left._{\mathrm{pw}}\right)$. 
Glutamic acid and glycine were the most abundant of the identified amino acids in DFAA, THAA THAA $_{\text {sed }}$, and THAA Tl+rh $_{\text {(Fig. 2), as also found in } 2}$ other studies of DFAA in seagrass sediments (Jørgensen et al. 1981, Boon 1986). The contribution (mole percent, mol\%) of unidentified amino acids in the upper $10 \mathrm{~cm}$ of the Zostera capricorni sediment increased from $3 \%$ in $\mathrm{THAA}_{\mathrm{rt}+\mathrm{rh}}$ through $8 \%$ in $\mathrm{THAA}_{\text {sed }}$ and $14 \%$ in $\mathrm{THAA}_{\mathrm{pw}}$ to $40 \%$ in DFAA. Similarly, Lomstein et al. (1998) found that the $\mathrm{mol} \%$ of unidentified amino acids increased from THAA $_{\text {sed }}(\sim 6 \%)$ and THAA $_{p w}$ $(\sim 13 \%)$ to DFAA $(\sim 26 \%)$ in an unvegetated sediment. In addition, Burdige \& Martens (1990) found that the mol\% of unidentified amino acids was higher in DFAA than in THAA $_{\text {sed }}$, and they suggested that the unidentified amino acids were transient intermediates in the mineralisation of protein amino acids. This was supported by Macko et al. (1994), who found that the content of protein amino acids in Halodule wrightii decreased by $\sim 50 \%$ during a decomposition study.

\section{Sources and sinks of ammonium}

Nitrogen is supplied to the sediment as particulate organic nitrogen (PON) and through nitrogen fixation (Fig. 5). In addition, dissolved inorganic nitrogen (DIN) is taken up from the water column by seagrass leaves and by benthic microalgae.

The average urea turnover rate in the vegetated sediment was $18 \mathrm{mmol} \mathrm{N} \mathrm{m}^{-2} \mathrm{~d}^{-1}$ and the nitrogen fixation was $4 \mathrm{mmol} \mathrm{N} \mathrm{m}^{-2} \mathrm{~d}^{-1}$, leading to a gross ammonium production of at least $22 \mathrm{mmol} \mathrm{m}^{-2} \mathrm{~d}^{-1}$ (Fig. 5). Denitrification and nitrification were not measured, but recent ${ }^{15} \mathrm{~N}$-tracer studies in sediments vegetated by Zostera marina and Zostera noltii indicate low rates
(Rysgaard et al. 1996, Risgaard-Petersen et al. 1998 Ottosen et al. 1999). The net requirement of nitrogen for growth of Zostera capricorni was $-3 \mathrm{mmol} \mathrm{m}^{-2} \mathrm{~d}^{-1}$. Uptake of nitrogen by seagrasses is assumed to occur both from the water column and the sediment with a maximum of $2 / 3$ of the demand supplied from one of the sources (Zimmerman et al. 1987, Pedersen \& Borum 1992). The plant uptake of nitrogen in the present study was relatively low compared to the gross ammonium production, which suggests, as there was no net ammonium production, a high rate of nitrogen incorporation into the bacteria. According to Blackburn (1983) the nitrogen incorporation into anaerobic bacteria can be estimated as $C_{0} \cdot N_{\mathrm{c}} \cdot E /(1-E)$, where $C_{\mathrm{o}}$ is the carbon oxidation rate, $N_{\mathrm{c}}$ is the $\mathrm{N} / \mathrm{C}$ ratio of bacterial cells, and $E$ is the efficiency of $C$ incorporation. Assuming that sulphate reduction was the only anaerobic process of importance for carbon oxidation, the anaerobic carbon oxidation should account for $-46 \mathrm{mmol} \mathrm{m}^{-2} \mathrm{~d}^{-1}$, resulting in an estimated nitrogen incorporation into anaerobic bacteria of $4 \mathrm{mmol} \mathrm{m}^{-2} \mathrm{~d}^{-1}$ ( $E=0.3$ and $N_{c}=0.2$ i Blackburn 1983). Similarly, the nitrogen incorporation into aerobic bacteria can be calculated if the respiration by aerobic bacteria is known. Nitrogen incorporation into aerobic bacteria in the present study was 7 to $21 \mathrm{mmol} \mathrm{m}^{-2} \mathrm{~d}^{-1}$, assuming that the aerobic respiration was responsible for 25 to $50 \%$ of the carbon oxidation ( $E=0.7$ and $N_{\mathrm{c}}=0.2$ ). In addition, nitrogen was presumably incorporated into benthic microalgae. Together with the observation that there was no net ammonium production, these estimates on nitrogen incorporation into the microbial biomass demonstrate high rates of internal nitrogen cycling in the sediment. We propose that mineralisation within the sediment, was through an almost closed cycle of alternate organic nitrogen degradation and resynthe-

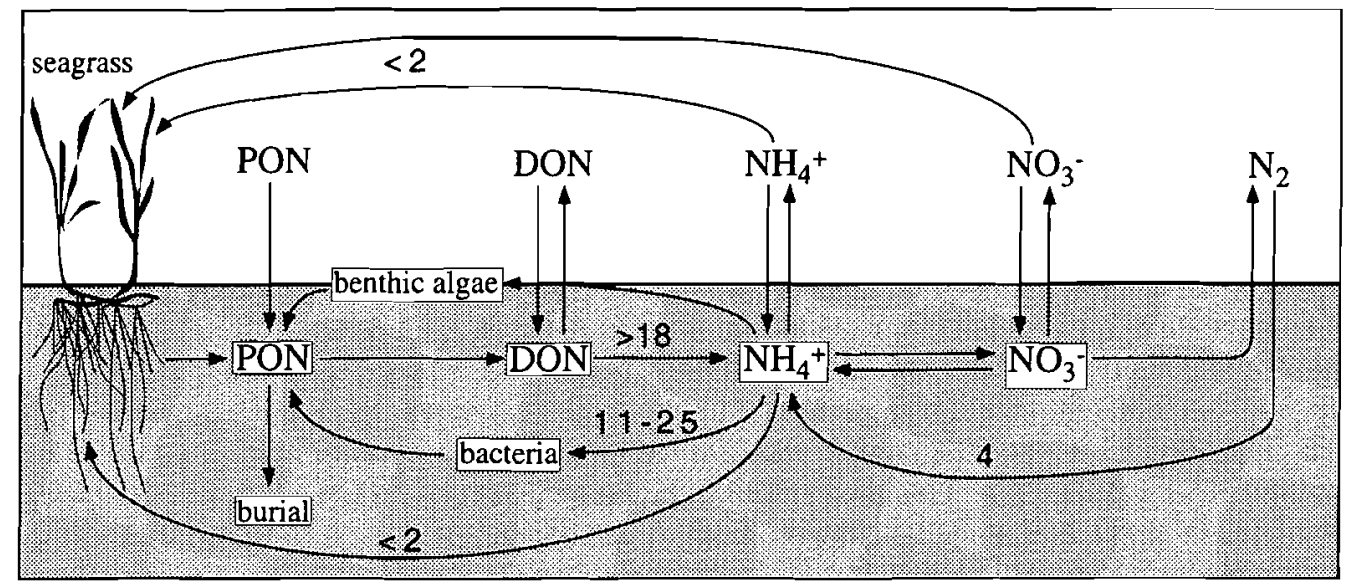

Fig. 5. Nitrogen cycle in the Zostera capricorni bed. Rates are presented as the mean of the rates obtained in the 10 and $50 \%$ light treatment and are given as mmol $\mathrm{N} \mathrm{m}^{-2} \mathrm{~d}^{-1}$. See text for further discussion 
sis, driven by carbon oxidation as also suggested by Lomstein et al. $(1989,1998)$. Z. capricorni functioned as a temporary storage of nitrogen and supplied, partly as leakage from root-rhizomes, some of the carbon that fuelled the recycling of nitrogen. The rapid recycling of nitrogen in an almost closed cycle within the sediment implies that porewater concentrations of nitrogen was kept low and that most of the nitrogen, at least temporarily, was unavailable to phytoplankton. Thereby, high microbial activity in the sediment and relatively high growth rates of seagrasses was sustained, despite the fact that Moreton Bay is characterised as a low nutrient environment (Boon 1986, Udy \& Dennison 1997).

In summary, the presence of Zostera capricorni stimulated the rates of nitrogen fixation, sulphate reduction, and to a lesser extent urea turnover in the sediment. The processes were enhanced in the rhizosphere, and there were high rates of nitrogen fixation and sulphate reduction associated directly with the root-rhizomes. This indicated a close nutritional association between the plant and the microorganisms attached to the root-rhizomes.

The stimulation of Zostera capricorni on sediment microbial processes was less pronounced at reduced light irradiance. Accordingly, reduced light availability in the water column will have an immediate effect on the microbial activity in vegetated sediments, and presumably the microbial activity will be displaced towards the water column as also found for plant growth.

Acknowledgements. We thank Eva Abal, Cynthia Heil, Karen Holloway, Rikke Holm, Ove Høegh-Guldberg, Benn Longstaff, Dorte Olsson, Jane Rogers, and Dorthe Siggaard for assistance during this study and people at CSIRO Cleveland Marine Laboratory for lending us their facilities. Three anonymous reviewers are acknowledged for constructive comments. Financial support was obtained from the Centre for Strategic Environmental Research in Marine Areas, Grant No. 4.15. This research was founded by the EU research programme 'Preserving the Ecosystem' under ROBUST project contract ENV4-CT96-0218. It is contribution ELOISE No. 154

\section{LITERATURE CITED}

Abal EG, Dennison WC (1996) Seagrass depth range and water quality in southern Moreton Bay, Queensland, Australia. Mar Freshw Res 47:763-771

Abal EG, Loneragan N, Bowen P, Perry CJ, Udy JW, Dennison WC (1994) Physiological and morphological responses of the seagrass Zostera capricorni Aschers. to light intensity. J Exp Mar Biol Ecol 178:113-129

Alcoverro T, Zimmerman RC, Kohrs DG, Alberte RS (1999) Resource allocation and sucrose mobilization in light-limited eelgrass Zostera marina. Mar Ecol Prog Ser 187 : $121-131$
Backman TW, Barilotti DC (1976) lrradiance reduction: effects on standing crops of the eelgrass Zostera marina in a coastal lagoon. Mar Biol 34:33-40

Blaabjerg V, Finster K (1998) Sulphate reduction associated with roots and rhizomes of the marine macrophyte Zostera marina. Aquat Microb Ecol 15:311-314

Blaabjerg V, Mouritsen KN, Finster K (1998) Diel cycles of sulphate reduction rates in sediments of a Zostera marina bed (Denmark). Aquat Microb Ecol 15:97-102

Blackburn TH (1983) The microbial nitrogen cycle. In: Krumbein WE (ed) Microbial geochemistry. Blackwell Scientific Publications, Oxford, p 63-89

Blackburn TH, Nedwell DB, Wiebe WJ (1994) Active mineral cycling in a Jamaican seagrass sediment. Mar Ecol Prog Ser 110:233-239

Boon PI (1986) Nitrogen pools in seagrass beds of Cymodocea serrulata and Zostera capricorni of Moreton Bay, Australia. Aquat Bot 25:1-19

Boon PI, Moriarty DJW, Saffigna PG (1986) Rates of ammonium turnover and the role of amino-acid deamination in seagrass (Zostera capricorni) beds of Moreton Bay, Australia. Mar Biol 91:259-268

Borum J, Sand-Jensen K (1996) Is total primary production in shallow coastal marine waters stimulated by nitrogen loading? Oikos 76:406-410

Bower CE, Holm-Hansen T (1980) A salicylate-hypochlorite method for determining ammonia in seawater. Can J Fish Aquat Sci 37:794-798

Burdige DJ, Martens CS (1990) Biogeochemical cycling in an organic-rich coastal marine basin: 11 . The sedimentary cycling of dissolved free amino acids. Geochim Cosmochim Acta 54:3033-3052

Caffrey JM, Kemp WM (1990) Nitrogen cycling in sediments with estuarine populations of Potamogeton perfoliatus and Zostera marina. Mar Ecol Prog Ser 66:147-160

Capone DG (1988) Benthic nitrogen fixation. In: Blackburn $\mathrm{TH}$, Sørensen $\mathbf{J}$ (eds) Nitrogen cycling in coastal marine environments. John Wiley and Sons, New York, p 85-123

Capone DG (1993) Determination of nitrogenase activity in aquatic samples using the acetylen reduction procedure. In: Kemp PF, Sherr BF, Sherr EB, Cole JJ (eds) Handbook of methods in aquatic microbial ecology. Lewis Publishers, Boca Raton, p 621-631

Capone DG, Taylor BF (1980) $\mathrm{N}_{2}$ fixation in the rhizosphere of Thalassia testudinum. Can J Microbiol 26:998-1005

Capone DG, Budin JM (1982) Nitrogen fixation associated with rinsed roots and rhizomes of the eelgrass Zostera marina. Plant Physiol 70:1601-1604

Connell EL, Colmer TD, Walker DI (1999) Radial loss from intact roots of Halophila ovalis as a function of distance behind the root tip and shoot illumination. Aquat Bot 63: $219-228$

Czerny $A B$, Dunton $K H$ (1995) The effects of in situ light reduction on the growth of two subtropical seagrasses, Thalassia testudinum and Halodule wrightii. Estuaries 18: $418-427$

Dennison WC (1987) Effects of light on seagrass photosynthesis, growth and depth distribution. Aquat Bot 27:15-26

Dennison WC, Alberte RS (1985) Role of daily light period in the depth distribution of Zostera marina (eelgrass). Mar Ecol Prog Ser 25:51-61

Dennison WC, Orth RJ, Moore KA, Stevenson JC, Carter V, Kollar S, Bergstrom PW, Batiuk RA (1993) Assessing water quality with submersed aquatic vegetation. Bioscience 43 : 86-94

Duarte CM (1991) Seagrass depth limits. Aquat Bot 40: 363-377 
Duarte CM (1995) Submerged aquatic vegetation in relation to different nutrient regimes. Ophelia 41:87-112

Duarte CM, Merino M, Agawin NSR, Uri J, Fortes MD, Gallegos ME, Marbá N, Hemminga MA (1998) Root production and belowground seagrass biomass. Mar Ecol Prog Ser 171:97-108

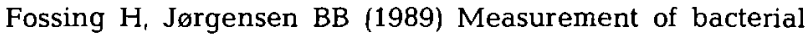
sulfate reduction in sediments: evaluation of a single-step chromium reduction method. Biogeochemistry 8:205-222

Glazebrook PW, Moriarty DJW, Hayward AC, MacRae IC (1996) Seasonal changes in numbers and the location of a particular bacterial strain of Alteromonas sp. in seagrass sediments. Microb Ecol 31:1-13

Goodman JL, Moore KA, Dennison WC (1995) Photosynthetic responses of eelgrass (Zostera marina L.) to light and sediment sulfide in a shallow barrier island lagoon. Aquat Bot $50: 37-47$

Hansen JW, Lomstein BAa (1999) Leakage of ammonium, urea, and dissolved organic nitrogen and carbon from eelgrass Zostera marina roots and rhizomes during sediment handling. Aquat Microb Ecol 16:303-307

Holmer M, Nielsen SL. (1997) Sediment sulfur dynamics related to biomass-density patterns in Zostera marina (eelgrass) beds. Mar Ecol Prog Ser 146:163-171

Hyland SJ, Courtney AJ, Butler CT (1989) Distribution of seagrass in the Moreton Region from Coolongatta to Noosa. Qld Dept of Primary Industries lnf Series Q189010, Brisbane, p 31

Lizumi $H$, Hattori A, McRoy CP (1982) Ammonium regeneration and assimilation in eelgrass (Zostera marina) beds. Mar Biol 66:59-65

Isaksen MF, Finster K (1996) Sulfate reduction in the root zone of the seagrass Zostera noltii on the intertidal flats of a coastal lagoon (Arcachon, France). Mar Ecol Prog Ser $137: 187-194$

Jørgensen BB (1978) A comparison of methods for the quantification of bacterial sulfate reduction in coastal marine sediments. Geomicrobiol J 1:11-27

Jørgensen NOG, Blackburn TH, Henriksen K, Bay D (1981) The importance of Posidonia oceanica and Cymodocea nodosa as contributors of free amino acids in the water and sediment of seagrass beds. PSZN I: Mar Ecol 2:97-112

Lee SY (1997) Annual cycle biomass of a threatened population of the intertidal seagrass Zostera japonica in Hong Kong. Mar Biol 129:183-193

Lindroth P, Mopper K (1979) High performance liquid chromatography determination of subpicomole amounts of amino acids by precolumn fluorescence derivatiozation with $o$-phathaldialdehyde. Anal Chem 51:1667-1675

Lomstein BAa, Blackburn TH, Henriksen K (1989) Aspects of nitrogen and carbon cycling in the northern Bering Shelf sediment. I. The significance of urea turnover in the mineralization of $\mathrm{NH}_{4}{ }^{+}$. Mar Ecol Prog Ser 57:237-247

Lomstein BAa, Jensen AGU, Hansen JW, Andreasen JB, Hansen LS, Berntsen J, Kunzendorf H (1998) Budgets of sediment nitrogen and carbon cycling in the shallow water of Knebel Vig, Denmark. Aquat Microb Ecol 14:69-80

Lund BAa, Blackburn TH (1989) Urea turnover in a coastal marine sediment measured by a ${ }^{14} \mathrm{C}$-urea short-term incubation. J Microbiol Methods 9:297-308

Macko SA, Engel MH, Qian Y (1994) Early diagenesis and organic matter preservation-a molecular stable carbon isotope perspective. Chem Geol 114:365-379

McGlathery KJ, Risgaard-Petersen N, Christensen PB (1998) Temporal and spatial variation in nitrogen fixation activity in the eelgrass Zostera marina rhizosphere. Mar Ecol Prog Ser 168:245-258
Moriarty DJW, Pollard PC (1982) Diel variation of bacterial productivity in seagrass (Zostera capricorni) beds measured by rate of thymidine incorporation into DNA. Mar Biol 72:165-173

Moriarty DJW, O'Donohue MJ (1993) Nitrogen fixation in seagrass communities during summer in the Gulf of Carpentaria, Australia. Aust J Mar Freshw Res 44:117-125

Moriarty DJW, Iverson RL, Pollard PC (1986) Exudation of organic carbon by the seagrass Halodule wrightii Aschers. and its effect on bacterial growth in the sediment. J Exp Mar Biol Ecol 96:115-126

Nelson TA, Waaland JR (1997) Seasonality of eelgrass, epiphyte, and grazer biomass and productivity in subtidal eelgrass meadows subjected to moderate tidal amplitude. Aquat Bot 56:51-74

O'Donohue MJ, Moriarty DJW, MacRae IC (1991) Nitrogen fixation in sediments and the rhizosphere of the seagrass Zostera capricorni. Microb Ecol 22:53-64

Olesen B (1996) Regulation of light attenuation and eelgrass Zostera marina depth distribution in a Danish embayment. Mar Ecol Prog Ser 134:187-194

Olesen B, Sand-Jensen K (1993) Seasonal acclimatization of eelgrass Zostera marina growth to light. Mar Ecol Prog Ser 94:91-99

Ottosen LDM, Risgaard-Petersen N, Nielsen NP (1999) Direct and indirect measurements of nitrification and denitrification in the rhizosphere of aquatic macrophytes. Aquat Microb Ecol 19:81-91

Patriquin D, Knowles R (1972) Nitrogen fixation in the rhizosphere of marine angiosperms. Mar Biol 16:49-58

Pedersen MF, Borum J (1992) Nitrogen dynamics of eelgrass Zostera marina during a late summer period of high growth and low nutrient availability. Mar Ecol Prog Ser 80: $65-73$

Pedersen MF, Duarte CM, Cebriàn J (1997) Rates of changes in organic matter and nutrient stocks during seagrass Cymodocea nodosa colonisation and stand development. Mar Ecol Prog Ser 159:29-36

Pedersen O, Borum J, Duarte CM, Fortes MD (1998) Oxygen dynamics in the rhizosphere of Cymodocea rotundata. Mar Ecol Prog Ser 169:283-288

Pedersen O, Borum J, Duarte CM, Fortes MD (1999) Errata to: 'Oxygen dynamics in the rhizosphere of Cymodocea rotundata. Mar Ecol Prog Ser 169:283-288'. Mar Ecol Prog Ser 178:310

Penhale PA, Smith WO Jr (1977) Excretion of dissolved organic carbon by eelgrass (Zostera marina) and its epiphytes. Limnol Oceanogr 22:400-407

Penhale PA, Wetzel RG (1983) Structural and functional adaptations of eelgrass (Zostera marina L.) to the anaerobic sediment environment. Can J Bot 61:1421-1428

Philippart CJM (1995) Effects of shading on growth, biomass and population maintenance of the intertidal seagrass Zostera noltii Hornem. in the Dutch Wadden Sea. J Exp Mar Biol Ecol 188:199-213

Pollard PC, Moriarty DJW (1991) Organic carbon decomposition, primary and bacterial productivity, and sulfate reduction, in tropical seagrass beds of the Gulf of Carpentaria, Australia. Mar Ecol Prog Ser 69:149-159

Price NM, Harrison PJ (1987) Comparison of methods for the analysis of dissolved urea in seawater. Mar Biol 94: 307-317

Risgaard-Petersen N, Dalsgaard T, Rysgaard S, Christensen PB, Borum J, McGlathery K, Nielsen LP (1998) Nitrogen balance of a temperate eelgrass Zostera marina bed. Mar Ecol Prog Ser 174:281-291

Rysgaard S, Risgaard-Petersen N, Sloth NP (1996) Nitrifica- 
tion, denitrification, and nitrate ammonification in sediments of two coastal lagoons in Southern France. Hydrobiologia 329:133-141

Sand-Jensen K (1975) Biomass, net production and growth dynamics in an eelgrass (Zostera marina L.) population in Vellerup Vig, Denmark. Ophelia, 14:185-201

Sand-Jensen K, Prahl C, Stokholm H (1982) Oxygen release from roots of submerged aquatic macrophytes. Oikos 38 : 349-354

Schmidt MA, Hayasaka SS (1985) Localization of a dinitrogen-fixing Klebsiella sp. isolated from root-rhizomes of the seagrass Halodule wrightii Aschers. Bot Mar 28: $437-442$

Shieh WY, Sinidu U, Maruyama Y (1989) Enumeration and characterization of nitrogen-fixing bacteria in an eelgrass (Zostera marina) bed. Microb Ecol 18:249-259

Short FT (1983) The response of interstitial ammonium in eelgrass (Zostera marina L.) beds to environmental perturbations. J Exp Mar Biol Ecol 68:195-208

Short FT, Wyllie-Echeverria S (1996) Natural and humaninduced disturbance of seagrasses. Environ Conserv 23: $17-27$

Short FT, Montgomery J, Zimmerman CF, Short CA (1993) Production and nutrient dynamics of a Syringodium filiforme Kütz. seagrass bed in Indian River Lagoon, Florida. Estuaries 16:323-334

Short FT, Burdick DM, Kaldy JE (1995) Mesocosm experiments quantify the effects of eutrophication on eelgrass, Zostera marina. Limnol Oceanogr 40:740-749

Smith GW, Hayasaka SS (1982a) Nitrogenase activity associated with Zostera marina from a North Carolina estuary. Can J Microbiol 28:448-451

Smith GW, Hayasaka SS (1982b) Nitrogenase activity associated with Halodule wrightii roots. Appl Environ Microbiol 43:1244-1248

Smith GW, Hayasaka SS, Thayer GW (1979) Root surface area measurements of Zostera marina and Halodule wrightii. Bot Mar 22:347-358

Editorial responsibility: Otto Kinne (Editor), Oldendorf/Luhe, Germany
Smith RD, Dennison WC, Alberte RS (1984) Role of seagrass photosynthesis in root aerobic processes. Plant Physiol 74: 1055-1058

Therkildsen MS, Lomstein BAa (1994) Seasonal variation in net benthic $\mathrm{C}$-mineralization in a shallow estuary. FEMS Microbiol Ecol 12:131-142

Therkildsen MS, King G, Lomstein BAa (1996) Urea production and turnover following the addition of AMP, CMP, RNA and a protein mixture to a marine sediment. Aquat Microb Ecol 10:173-179

Thursby GB (1984) Root-exuded oxygen in the aquatic angiosperm Ruppia maritima. Mar Ecol Prog Ser 16: 303-305

Udy JW, Dennison WC (1997) Growth and physiological responses of three seagrass species to elevated sediment nutrients in Moreton Bay, Australia. J Exp Mar Biol Ecol 217:253-277

Welsh DT, Bourguès $S$, de Wit R, Herbert RA (1996) Seasonal variations in nitrogen-fixation (acetylene reduction) and sulfate-reduction rates in the rhizosphere of Zostera noltii: nitrogen fixation by sulfate-reducing bacteria. Mar Biol 125:619-628

Welsh DT, Bourguès S, de Wit R, Auby I (1997) Effect of plant photosynthesis, carbon sources and ammonium availability on nitrogen fixation rates in the rhizosphere of Zostera noltii. Aquat Microb Ecol 12:285-290

Wetzel RG, Penhale PH (1979) Transport of carbon and excretion of dissolved organic carbon by leaves and root/ rhizomes in seagrasses and their epiphytes. Aquat Bot 6: $149-158$

Wium-Andersen S, Borum J (1984) Biomass variation and autotrophic production of an epiphyte-macrophyte community in a coastal Danish area: I. Eelgrass (Zostera marina L.) biomass and net production. Ophelia 23:33-46

Zimmerman RC, Smith RD, Alberte RS (1987) Is growth of eelgrass nitrogen limited? A numerical simulation of the effects of light and nitrogen on the growth dynamics of Zostera marina. Mar Ecol Prog Ser 41:167-176

Submitted: August 20, 1999; Accepted: December 13, 1999 Proofs received from author(s): May 25, 2000 